\title{
THE EFFECT OF PLAYING PUZZLE THERAPY ON THE FINE MOTORIC DEVELOPMENT OF PRE-SCHOOL CHILDREN IN TK TUNAS HARAPAN BATOKAN KASIMAN
}

\author{
Mohamad Da' $\mathrm{i}^{*}$, Ira Emeilia Maulidaty ${ }^{2}$ \\ ${ }^{1 *}$ Universitas Nahdlatul Ulama Sunan Giri, Bojonegoro, East Java, Indonesia \\ ${ }^{2}$ Universitas Negeri Malang, Malang, East Java, Indonesia \\ dai@unugiri.ac.id, iraemeilia@gmail.com
}

DOI: https://doi.org/10.21107/Widyagogik/v8i2. 8983

Received November 04, 2020; Revised February 10, 2021; Accepted March 21, 2021

Abstract

Yuniati's research (2018) at TK At Taqwa Mekarsari Cimahi found that 17 people in the puzzle intervention group found that most of the children before being given a puzzle type educational game, had moderate fine motor skills (64.7\%), the rest was (35.3\%) ) respondents have low fine motor development. The research objective was to determine the effect of playing puzzle therapy on fine motoric development in preschool children at TK Tunas Harapan Batokan Kasiman in 2021. This type of research was pre-experimental with a one group pretest-posttest approach. The sample in this study were 15 children. The sampling technique used total sampling. Data collection was by means of observation on February 1, 2021. The data were analyzed univariately and bivariately using statistical test paired samples T-test. The results of the study were the mean fine motor development before being given puzzle playing therapy at TK Tunas Harapan Batokan Kasiman with a mean value of 7.87, standard deviation of 1.246. The average fine motoric development after being given puzzle playing therapy at TK Tunas Harapan Batokan Kasiman with a mean value of 9.93 standard deviation is 1.534 . There is an influence on the fine motoric development of children before and after playing puzzle therapy at TK Tunas Harpan Batokan Kasiman in 2021 with a p-value $(0,000)$. The conclusion of the research on playing puzzle therapy can affect fine motor skills in children. It is hoped that puzzle playing therapy can be applied in TK Tunas Harapan Batokan Kasiman. And it is hoped that this research can be developed with other therapies to see the fine motor development of pre-school children.

Keywords - Puzzle play therapy, Fine motor development, Children. 
80 The effect of playing puzzle therapy on the fine motoric development of pre-school children in

TK Tunas Harapan Batokan Kasiman

Mohamad Dai; Ira Emeilia Maulidaty

\section{Introduction}

Preschool children are children aged 3-6 years. At this age children generally participate in the children's program ( 3 years - 5 years) and play groups ( 3 years), while at 4-6 years they usually attend Kindergarten programs (Patmonedowo, 2008). Interrelated between biological processes, socioemotional processes and cognitive processes. These three things will influence each other and throughout the course of human life. During the development process it is possible for children to face various problems that will hinder the subsequent development process. This development includes the development of social, language, cognitive, physical / motoric behavior ( $\mathrm{MOH} .2012$; Setyawan, Aznam, Paidi, \& Citrawati. 2020) Good fine motor skills, in order to determine someone to do good activities too, for example combing hair, putting on shoelaces, buttoning clothes, writing and so on. other. This will support activities in everyday life, especially for yourself, not all motor development can run smoothly, because it is influenced by many factors. One of the environmental factors, physical structure, maturity, opportunity, learning and training (Fitri, 2012).

Motor skills can be developed through play activities related to physical skills that involve small muscles and coordination between the eyes and hands, such as playing puzzles, maze, composing blocks, inserting objects into holes according to their shapes, making lines, folding paper, and writing with letters. according to its shape (Decaprio, 2013). Puzzles are a type of game in the form of pieces of images that how to play, namely by arranging them so that an image is formed, with the aim of training patience, making it easier for students to understand concepts, solve problems, cooperate with friends, and develop motor and cognitive skills. student. (Herawati, 2013)

The results of research conducted by Lilis (2018) regarding the Puzzle Playing Method Influence the Fine Motoric Development of Pre-School Ages conducted in Bojonegoro, most of the development of preschool-aged children before being given the puzzle playing method was normal as many as 26 children (59\%) of 44 children. After being given the method of playing puzzles, there was an increase in fine motor development, as many as 38 children.

The results of research conducted by Erni Yuniati (2018) on Puzzles Influencing Fine Motoric Development of Pre-School Age Children at Kindergarten At Taqwa Mekarsari Cimahi, it was found that 17 people in the puzzle intervention group found that most children before being given educational games with puzzle types, had moderate fine motor skills. namely $(64.7 \%)$, the rest $(35.3 \%)$ of respondents had low fine motor development.

After the intervention of the puzzle type educational game, most of the children with fine motor skills were in high criteria, namely (64.7\%), children with very high fine motor development $(23.5 \%)$ and the rest $(11.8 \%)$ respondents had moderate fine motor skills. Based on data from the Bojonegoro City Education Office in 2021 there are 305 kindergarten schools, after researchers made observations at two kindergarten schools in the Bojonegoro area, from the results of interviews with the principal and homeroom teacher of TK Dharma Wanita said that puzzle games have been 
implemented for fine motoric development in children. , and at TK Dharma Wanita has a theme that is applied every day, while the puzzle game at TK Tunas Harpan Batokan Kasiman only occasionally applies the game, because in TK Tunas Harapan Batokan Kasiman this in motor development uses picture cards, arranges blocks, and does not exist. applying a theme such as TK Dharma Wanita.

After conducting an initial survey of researchers at TK Tunas Harpan Batokan Kasiman in class B, the number of students in the kindergarten was 20 people. From the observation, there are 5 children who have problems with fine motor development, it can be seen from the fact that the children are still less able to draw and color neatly because they are still stiff in holding pencils or crayons. Based on the above phenomena and facts, the researcher is interested in conducting a research entitled "The Effect of Puzzle Playing Therapy on Fine Motor Development in Pre-School Children in Kindergarten Tunas Harapan Batokan Kasiman in 2021".

\section{Method}

This research was conducted in TK Tunas Harapan Batokan. This type of research is pre-experimental with the one groupapproach pretest-posttest. Population is the whole of the research object or object under study. The population in this study were all of the kindergarten students in class B as many as 15 people with a total sampling technique. The data collection technique used in this study was primary data collection by performing observation sheets of fine motor skills before and after playing therapy. This study used Univariate analysis with the distribution of mean fine motor skills before and after playing therapy and Bivariate analysis using the statistical t-test paired samples. $(<0.05)$.

\section{Result and Discussion}

Table 1. Average Fine Motor Development Before being given Playing Therapy Puzzle at Kindergarten Tunas Harapan Batokan in 2021

\begin{tabular}{|cccc|}
\hline $\begin{array}{c}\text { Development } \\
\text { Fine motor }\end{array}$ & $\mathbf{n}$ & Mean & $\begin{array}{c}\text { Standard } \\
\text { Deviation }\end{array}$ \\
\hline Before & 15 & 7,87 & 1,246 \\
\hline
\end{tabular}

Based on table 1 it can be seen that the average fine motor development before therapy is given playing puzzles in TK Tunas Harapan Batokan with a mean value of 7.87 standard deviation 1.246 .

The results of this study are almost the same as Maghfuroh's (2018) research on the effect of usingplaying methods puzzle on the fine motor development of preschool children in kindergarten. Surya Baru Desa Plosowahyu Lamongan found the results 
82 The effect of playing puzzle therapy on the fine motoric development of pre-school children in TK Tunas Harapan Batokan Kasiman

Mohamad Dai; Ira Emeilia Maulidaty

before being given play therapy with a mean of $59 \%$. There is an effect of the use of playing methods with the fine motoric development of children with $p$ value $=0.001$. In addition, this study is in line with Warsih's (2021) Puzzle Influencing Fine Motoric Development of Preschoolers at TK Tunas Harapan Batokan Kasiman, it was found that the mean results were before 3.35. There is an effect ofgames puzzle on fine motoric development in children with $\mathrm{p}$ value $=0.0001$.

According to Susanto (2011) fine motor skills are movements that involve finer movements performed by good muscles. These subtle movements require careful coordination. The better the fine motor movements so that the children can be creative. Magical in (Sumantri, 2005) this fine motor skill involves neuromuscular coordination (muscle nerves) which requires a high degree of determination for the success of this skill. This skill is often referred to as a skill that requires eyes and hands (hand-eyes coordination).

According to the researcher's analysis, fine motor development in children in kindergarten. The nucleus of Tulip Group III before being givenplaying therapy puzzle with an average of 7.87. The low fine motor skills in children are due to environmental factors and children's personalities which can also affect delays in motor development. Children who are often spoiled by their parents often experience delays in fine motor development. Where parents often prohibit children from using scissors, playing with hard objects so that the child's fine motor development is delayed.

Table 2. Average Fine Motor Development After being given Playing Therapy Puzzle at Kindergarten Tunas Harapan Batokan in 2021

\begin{tabular}{|cccc|}
\hline $\begin{array}{c}\text { Development } \\
\text { Fine motor }\end{array}$ & n & Mean & $\begin{array}{c}\text { Standard } \\
\text { Deviation }\end{array}$ \\
\hline After & 15 & 9,93 & 1,534 \\
\hline
\end{tabular}

Based on table 2 it can be seen that the average fine motor development after being givenplaying therapy puzzle at TK Tunas Harapan Kasiman with a mean value of 9.93 standard deviation of 1.534 .

The results of this study are almost the same as Maghfuroh's (2018) research on the effect of usingplaying methods puzzle on the fine motor development of preschool children in kindergarten. Surya Baru Desa Plosowahyu Lamongan found the results before being given play therapy with a mean of $88.4 \%$. There is an effect of the use of playing methods with the fine motoric development of children with $p$ value $=0.001$. In addition, this research is in line.In addition, this research is in line with Yuniati (2018) Puzzles Influencing Fine Motoric Development of Preschool Children at TK At Taqwa Mekarsari Cimahi found mean results after 1.88. There is an effect ofgames puzzle on fine motoric development in children with $p$ value $=0.0001$. 
The Playing Method Puzzle affects the Fine Motor Development of Preschoolers, because playing puzzles can coordinate children's eye and hand movements, thereby without realizing their fine motor skills continue to be trained and develop properly. In addition, when they play puzzles, children can practice recognizing shapes and how they fill in the empty spaces where the pieces are needed. Puzzles also encourage children to recognize similarities, such as how a red color or a thick line in a piece matches the same pattern on another piece. Through this game children can learn that an object or object is composed of small parts. This game encourages children to understand how to combine different elements (Andriana, 2011).

According to the researcher's analysis, there is fine motor development in children in kindergarten. The nucleus of the Tulip Group III after being givenplaying therapy puzzle with an average of 9.93. Playing puzzles is a simple play media that is played in pairs that require accuracy, because children are trained to be able to focus their minds in order to concentrate, in addition to playing puzzles children learn about the concepts of shapes, colors, sizes and quantities that can help develop children's fine motor skills. by involving the coordination of the eyes and hands and training the muscles of the fingers.

Table 3. Average Effect of Children's Fine Motor Development Before and After Playing Therapy Puzzle at Kindergarten. Core of Tulip Cluster III

\begin{tabular}{|c|c|c|c|c|c|c|c|c|}
\hline & 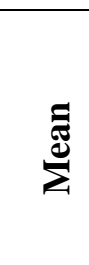 & $\mathbf{N}$ & SD & $\sum_{\dot{\infty}}^{\stackrel{\grave{0}}{\Delta}}$ & $\mathbf{t}$ & $\begin{array}{r}\text { onfide } \\
\text { D }\end{array}$ & nterval & 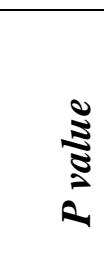 \\
\hline & & & & & & & Upper & \\
\hline 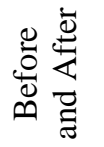 & 2,07 & 15 & 1,387 & 0,358 & $-5,771$ & $\begin{array}{c}- \\
2,8 \\
3\end{array}$ & $-1,30$ & 0,000 \\
\hline
\end{tabular}

Based on table 3 shows the mean difference in fine motor development before and after therapy puzzles is the mean of 2.07. After the statistical test of paired samples T-test, theobtained $p$ value was $(0.000) \alpha<0.05$. So there is an influence on the fine motoric development of children before and after playingtherapy puzzle at TK Tunas Harpan Batokan Kasiman in 2021.

The results of this study are almost the same as Maghfuroh's research (2018), it was found that there were differences before and after being givenplaying therapy, the puzzle difference in mean was 4,6 . After the statistical test of paired samples T-test, the $p$ value was $(0.002)<\alpha 0.05$. So there is an effect of the use of puzzle playing methods that affect the fine motor development of preschool children. The results were found before being givenplaying therapy puzzle. 
84 The effect of playing puzzle therapy on the fine motoric development of pre-school children in

TK Tunas Harapan Batokan Kasiman

Mohamad Dai; Ira Emeilia Maulidaty

In addition, this study is in line with Yuniati (2018) Puzzles Influencing Fine Motor Development of Preschool Children at TK At Taqwa Mekarsari Cimahi, it was found that there was an effect of giving puzzle therapy on the fine motor development of preschool aged children ( $p$ value $=0.001$ ).

Motor skills can be developed through play activities related to physical skills that involve small muscles and coordination between the eyes and hands, such as playing puzzles (Decaprio, 2013). Puzzles are a type of game in the form of pieces of images that are played by arranging them so that an image is formed, with the aim of training patience, making it easier for students to understand concepts, solve problems, cooperate with friends, and develop motor and cognitive skills of students. (Herawati, 2013) The researchers' analysis of the differences before and after theplaying therapy treatment puzzle found a difference in the improvement ofplaying therapy puzzle with a difference of 2.07. This is because after 25 minutes of treatment each child found changes. Before the treatment, 3 people were low, 11 people were high and 1 person was very high in the puzzle. After the treatment, the results showed that 1 child was still low, 5 children were tall and 9 children had very high motor skills. Playing puzzles can improve fine motor skills, which is an ability that deals with small muscles, especially the hands and fingers, and trains eye and hand coordination. Through playing puzzles, children will learn to actively use their fingers to compose the right picture without realizing it.

\section{Conclusion}

Mean of fine motoric development before being givenplaying therapy puzzle in TK Tunas Harpan Batokan Kaiman with a mean value of 7.87, standard deviation is 1.246. The average fine motoric development after being givenplaying therapy puzzle at TK Tunas Harapan Batokan Kasiman with a mean value of 9.93 standard deviation is 1.534. There is an influence on children's fine motoric development before and after playingtherapy puzzle at TK Tunas Harpan Batokan Kasiman in 2021.

\section{References}

Adriana. 2011. Tumbuh Kembang dan Terapi Bermain Pada Anak. Jakarta: Salemba Medika

Decaprio, 2013. Aplikasi Pembelajaran Motorik di Sekolah. Jogjakarta: Diva Press

Depkes RI. 2006. Pedoman Pelaksanaan Stimulasi Deteksi dan Intervensi Dini Tumbuh Kembang Anak ditingkatPelayanan Kesehatan Dasar.

Desmita. 2009. Psikologi PerkembanganPeserta Didik. Bandung : PT RemajaRosdakarya 
Febrina. 2015. Pengaruh Alat Permainan Edukatif Maze Alur Tulis Terhadap Keterampilan Motorik Halus Pada Anak Kelompok A TK ABA Janturan Umbulharho Yogyakarta.

Fitri. 2012. Meningkatkan Motorik Halus Dalam Memegang Alat Tulis Melalui Teknik Mencongkel Bagi Anak Autis.1 (2)

Herawati. 2013. Pembelajaran Kooperatif TAl dan game puzzle dalam meningkatkan motivasi belajar danpemahaman konsep.

Junaidi. 2011. Kehamilan Sehat Dan Mengatur Jenis Kelamin Anak. Yogyakarta: C.V ANDI OFFESET

Maghfuroh, 2018. Metode Bermain Puzzle Berpengaruh pada Perkembangan Motorik Halus Anak Usia Prasekolah di TK. Surya Baru Desa Plosowahyu Lamongan, Jurnal Skripsi

Nabiel. 2014. Buku Ajar Keperawatan Anak. Yogyakarta : Pustaka Pelajar

Nidho. 2013. Upaya Meningkatkan Pengenalan Geometri Dengan Permainan Puzzle Bervariasi Pada Kelompok B TK AL-HIKMAH Randudongkal-Pemalang.

Notoatmodjo. 2012. Metodologi Penelitian Kesehatan, Jakarta : Rineka Cipta

Patmonodewo. 2008. Pendidikan Anak Pra Sekolah. Jakarta : Rineka Cipta

Setyawan, A., Aznam, N., Paidi, P., \& Citrawati, T. (2020). Influence of the use of technology through problem based learning and Inkuiri models are leading to scientific communication students class VII. Journal of Technology and Science Education, 10(2), 190-198. doi:http://dx.doi.org/10.3926/jotse.962

Sumatri. 2005. Pengembangan Keterampilan Motorik Anak Usia Dini. Jakarta : Dinas Pendidikan

Susanto, 2011. Pengembangan Anak Usia Dini Pengantar dalam Berbagai Aspeknya. Jakarta : Kencana Perdana Media Group

Wong. 2009. Buku Ajar Keperawatan Pediatrik. Jakarta : EGC

Yuniarni. 2010. Metode Pengembangan Anak Usia Dini : Pontianak

Yuniati. E, 2018. Puzzle Mempengaruhi Perkembangan Motorik Halus Anak Usia Pra Sekolah di TK At Taqwa Mekarsari Cimahi.11 (1) 